Please note that this is a so-called personal version (author's manuscript as accepted for publishing after the review process but prior to final layout and copyediting) of the article:

Wahlen, S. \& Laamanen, M. (2015) Consumption, lifestyle and social movements. International Journal of Consumer Studies, 39 (5), 397-403. DOI: 10.1111/ijcs.12237

Readers are kindly asked to use the official publication in references.

\title{
Consumption, lifestyle and social movements
}

Stefan Wahlen ${ }^{1}$ and Mikko Laamanen ${ }^{2}$

\begin{abstract}
In this editorial, we contemplate how the politics of the everyday in consumption and consumer lifestyles emerge. Foundational here is the overarching question why, how and where do people come to share common spaces, meaning, identity, practice and goals in dispersed lifestyles aiming for (social) change. This special issue is an original endeavour to generate an understanding of the issues, problems and potential for change emerging from individual and collective efforts in and around consumption and lifestyles. The editorial presents principles and commonalities of the intersectional study of consumption, lifestyle and social movements. We connect these principles with the papers that make up the special issue and conclude with an outlook for future research.
\end{abstract}

Keywords: Consumption, lifestyle, social movement, politics, everyday, research agenda

\section{Introduction}

In recent years, we have noticed interesting developments between social movement research and consumer studies (Balsiger, 2010; Bossy 2014; Dubuisson-Quellier, 2013; Haenfler et al., 2012; Holzer, 2006; Kozinets \& Handelman 2004; Micheletti, 2003; Portwood-Stacer, 2012; Stolle et al., 2005; Yates 2011, 2015). Studies in this intermediary research arena where firms, consumers, and social movements meet often consider collective action as direct activism against the (mis-)behaviour of corporations as well as contestating the relational dynamics of market relationships (e.g. King, 2011; Kozinets \& Handelman 2004; Laamanen\& Skålén, 2014; Moraes et al., 2010; Soule, 2012; Varman \& Belk, 2009).

\footnotetext{
${ }^{1}$ Sociology of Consumption and Households, Wageningen University, Wageningen, The Netherlands

${ }^{2}$ Department of Marketing \& Centre for Relationship Marketing and Service Management (CERS), Hanken School of Economics, Finland
} 
Consumer activism is practiced, amongst others, through protesting, adbusting and boycotting, whereby both the bottom-line of individual companies and politico-economic systems are pronounced targets.

Examining collective action within the larger framework of consumption particularly seeks to answer to calls for research that expands the understanding of social movement actions. Social change can be brought about through challenging political, but also economic and cultural authority structures (Johnston \& Klandermans, 1995; Snow, 2004). This activity is located in the politics of the everyday. Recently, in a seminal article, Haenfler, Johnson and Jones (2012) conceptualized lifestyle movements as the conjuncture of the private and public forms of enacting and living the social change, based on shared lifestyles and identity that exist beyond or even aside political goals, challenging cultural and economic social practices, ultimately aiming for wider social, cultural or economic change.

In consumer studies, current debates highlight the "motley images" of the consumer (such as citizen, activist, rebel, etcetera; see e.g. Farrell, 2010; Gabriel \& Lang, 2006; Klintman \& Boström, 2006) who, by making particular choices and engaging in various practices influence systems of provision towards more ethical and sustainable futures. Consumption practices embody agency and elucidate how actors in their everyday life activities make sense of and construct their socio-economic and cultural surroundings. Duly, consumer studies scholarship acknowledges consumers' political agency and subsequent potential to enact social change (Forno \& Graziano, 2014; Halkier \& Holm 2008). Moreover, while lifestyles are particularly both salient and instrumental to consumption, e.g. representing consumers' life projects (Frrat \& Venkatesh, 1995; Giddens, 1991; Haanpää, 2007; Holt, 1997; Lury, 2011), their political nature is often secondary consideration in comparison to their quality as an instrument building and sustaining market relationships and position, e.g. through brand loyalty. Elaborating on the politics of consumer lifestyles thus provides an au currant and coherent connection between social movement theories and consumer studies research, and allows for the creation of new insights in both fields.

Precisely this will be our departure point for this special issue of the International Journal of Consumer Studies, which thematically builds on a special issue of this journal published in 2006, emphasising 'political and ethical consumerism around the world' (Klintman \& Boström, 2006, pp. 401). In what follows, we aim to extend the notion of the consumer as political agent emphasising how everyday acts contributing to social change and the politics of consumption (Ginsbourg, 2005). Theoretically we call for a reorientation that 
(1) acknowledges the genealogy of the understanding or conceptualisation of what or who is a consumer (cf. Gabriel \& Lang, 2006; Trentmann, 2006), and (2) moves the discussion beyond hegemonic understandings of the individual consumer as market participant acknowledging, on the one hand, the various roles of consumers and their conglomerations, and on the other, the various, routinized and even banal everyday collective activities and resistance as the politics of the everyday (e.g. de Certeau, 1984; Glickman, 2009; Haenfler et al. 2012; Wahlen, 2011).

In this sense, this special issue on Consumption, Lifestyle and Social Movements is a novel endeavour to bridge these relevant literatures and areas of research in social movement research on the one and consumer studies scholarship on the other hand. We attempt to understand issues, challenges and potential for social change emerging in and around consumption and lifestyles. It is possible to witness a pronounced multitude of research that needs further synthesising and theorising for the study of consumption, lifestyles and social movements. Three central streams of examination can be highlighted based on the articles that have been submitted to this special issue: (1) political consumption and lifestyles, (2) organisations and mobilising spaces, and (3) mechanisms of mobilisation. In the remainder of this editorial, we discuss how these different categories exemplify contexts for the intersectional study of consumption as shared ways of living, identity and collective action. Concluding from the various theoretical and empirical contributions, a research agenda for the future is put forward.

\section{Consumption as politics of the everyday in localised, mobilised lifestyles}

The interface of social movement research and consumer studies is a promising terrain of investigation as outlined in the introduction. The aim of this special issue and the papers included therein is to highlight similarities between the hitherto disparate literatures. Furthermore, the purpose is to extend discussions beyond the traditional negation of consumption and lifestyles as individualistic and hedonistic acts uncritical of their performance, their location in the marketplace, or outcomes in social, economic, and environmental terms. Consumption as social phenomenon transcends individualism and collectivism. The paradox of the collective character of individual activity with the intention of social change raises an important and interesting question: Why, how and where do people 
come to share a common space, meaning, identity, practice and goals in dispersed lifestyles?

Central to this question is how mobilisation of lifestyles takes place.

Classically social movement theory treats mobilisation as based on and dependent of a common grievance as well as individual willingness and collective mechanisms to challenge or maintain certain social order (for an overview see e.g. Snow \& Soule, 2010). Departing from the traditional social movements of the modern era (most pronouncedly the labour movement), some argue that in the late modern globalised society, class politics are substituted by identities and lifestyles. According to Della Porta and Diani (2006), lifestyles express either individualist consumer(ist) behaviour, or are key to understanding the on-going conflicts between new and traditional cultural forms of social activity. In a similar vein, Giddens (1991) contends that lifestyles are salient in consumption; he further elaborates (1991, pp. 81, emphasis added) lifestyles as

...a more or less integrated set of practices which an individual embraces, not only because such practices fulfil utilitarian needs, but because they give material form to a particular narrative of self-identity. Lifestyle ... implies choice within a plurality of possible options ... is 'adopted' ... [and] are routinised practices, the routines incorporated into habits of dress, eating, modes of acting and favoured milieux for encountering others; but the routines followed are reflexively open to change in the light of the mobile nature of self-identity ... [everyday] choices (as well as in larger and more consequential ones) are decisions not only about how to act, but who to be. The more post-traditional the settings in which an individual moves, the more lifestyle concerns the very core of self-identity, its making and remaking.

Lifestyles as a set of consumption practices can become the clue that connects individuals in political everyday projects and offer insight into how consumption-based lifestyles become and remain localised and mobilised. Lifestyles are enacted in the private, they may remain hidden from the public gaze. In contrast to recent very public protests like the Arab Spring or Occupy camps worldwide, alternative lifestyles are often less visible or latent. They do, however, define spaces for resistance in the otherwise restrictive context (see e.g. Futrell and Simi, 2004; Reedy, 2014). The general inconspicuousness of lifestyles is related to how they are '...(1) relatively individualized and private, (2) ongoing rather than episodic, and (3) aimed at changing cultural and economic practices rather than targeting the state' (Haenfler et al., 2012: 6).

Accordingly, consumption and lifestyles are important to understanding the dynamics between private and the public, and individual and collective. Where some consider 
consumption as inherently solitary and private (e.g. Bauman, 2005), it's the visible consequences of that private act out of which activism emerges - such as the various forms of abstinence exemplified in Haenfler et al. (2012) or in the aesthetics of countercultures, such as punk culture, that have transcended disdain and gradually become culturally more mainstream and appropriated. The individualistic pleasure of consumption and lifestyle can become a cross to bear if engagement in consumption aims for change yet carries with it the burden of individualized responsibility (e.g. Moisander, 2007; Wahlen, 2009). Problematically, in a hyper-individualised society, lifestyles can provide a means of connection to individuals who are otherwise disconnected and share little in common (cf. Lichterman, 1996).

In the following figure 1, we conceptualise a way to theoretically understand and empirically approach the question how lifestyles and consumption embody everyday politics. Consumption and lifestyles are localised and mobilised; i.e. have on the one hand spatial, temporal and praxeological relevance and are on the other hand of collective, contentious and ideological nature (cf. Yates, 2015). Various collectivities manifest around local and global problems in, for example, demonstrations against austerity or corporate misconduct or to build subsistence systems that try to meet the needs of local population in the absence or malfunction of markets and/or public provision. Politics, on the other hand, require some formation of collective identity and goals that have ideological roots and are contentious to either looming change or the status quo.

Figure 1. Consumption and lifestyle as everyday politics

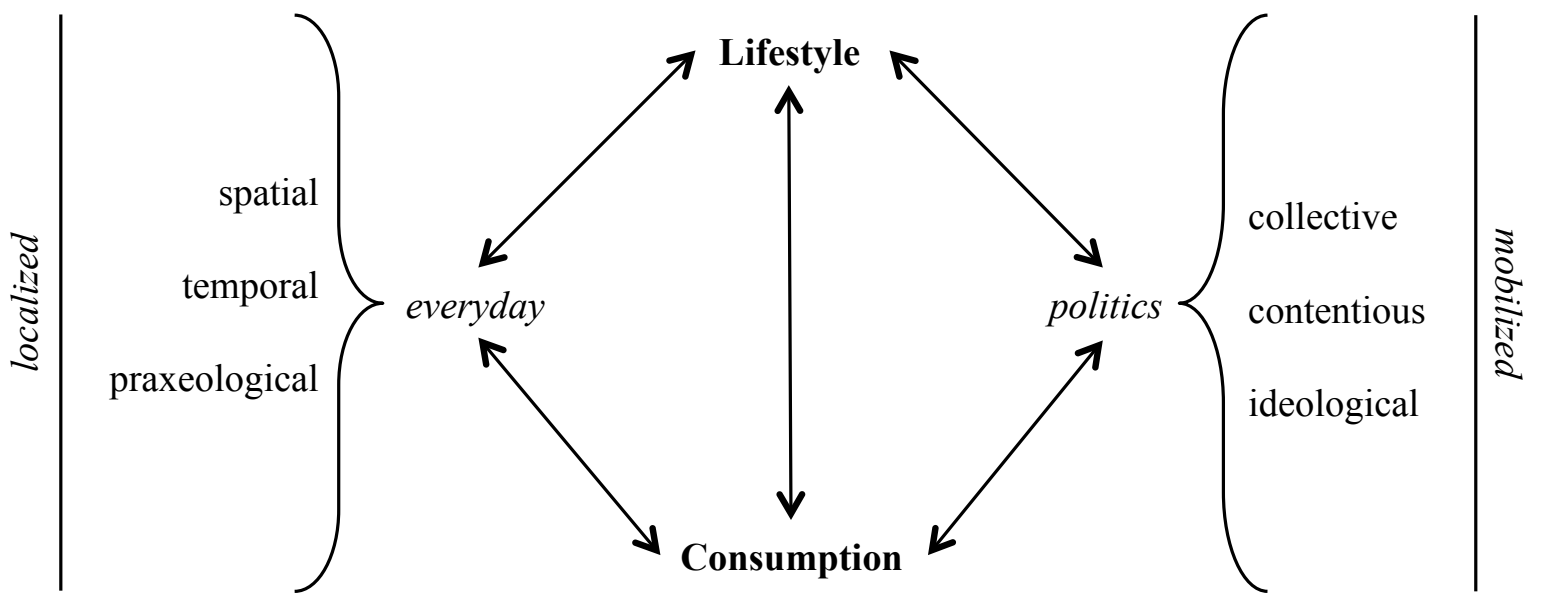


The way in which consumption practices emerge in the everyday follows a definition by Warde (2005: 137) understanding consumption '... as a process whereby agents engage in appropriation and appreciation, whether for utilitarian, expressive or contemplative purposes, of goods, services, performances, information or ambience, whether purchased or not, over which the agent has some degree of discretion'. Coinciding with the aforementioned Giddensian understanding of lifestyles, the essence of practice theoretical understandings of consumption lies in routines (Wahlen, 2011; Warde, 2005). Practices, although shared, are individual in their execution and spatially bound in households and communities, and temporally in the everyday. These characteristics along with ideological guidance of a movement render action in the everyday prefigurative inasmuch as they attempt to create the future in the practical ways of doing today: change requires resistance to what are the social (consumption) practices in the present (Haenfler et al., 2012; Maeckelbergh, 2009; Yates, 2015).

Based on the articles in this special issue we identify three particular streams of investigation related to the framework above. First, political consumption and lifestyles questions the current paradigms in studying consumers and movements. The articles extend current notions of political consumerism by uncovering some empirical evidence on the instances in lifestyles, but also in more concrete examples such as fair trade consumption or furnishing apartments. The second stream considers organisations and mobilising spaces around particular ways of life, such as urban food cultivation, local exchange systems, and eco-villages. Where these lifestyles are spatially bound, we can further observe attempts to use social media, such as Facebook or Twitter, for organising and mobilising consumers beyond spatial boundaries. The third and last stream of articles in this special issue then looks more specifically at mechanisms of mobilisation; including mobilisation as collaboration with more traditional social movement organisations, drawing on consumer cynicism and coping strategies, and the implications of motivating and empowering consumers to and for social change.

\section{Political consumption and lifestyles}

In this stream of the special issue we explore historical-genealogical perspectives criticising traditional understandings of political consumption movements as well as provide empirical examples. The papers show that consumption is indeed political in terms of making 
statements with the shopping basket; yet it extends beyond individual activity to bridging individualism and collectivism by '...building bonds of solidarity and cooperation among people, bonds which are a fundamental resource for collective action' (Forno \& Graziano, 2014, pp. 145).

Dubuisson-Quellier (2015) describes in her article "From targets to recruits: the status of consumers within the political consumption movement" how social movement organisations urge consumers to become more responsible. With the changing modes of consumption lifestyles, the notion of political consumption seems to become a key objective in a consumer-oriented, collective action framework. However, the paper shows that rather than trying to change mass consumer consumption patterns, these social movement organisations actually seek to recruit consumers to support their causes targeting companies and governments. The article discusses the notion of political consumerism as leading to deadlock - it is impossible to demonstrate political shifts in consumption or attribute them to social movement actions. The article stresses that political consumption movements rely less on the occurrence of a hypothetical political consumerism among mass consumers and more on the organisation of collective action among politicized consumers committed to targeting companies and governments for change.

In a similar vein, Baumann et al. (2015) discuss in their article "Shopping for change?: Political consumption, conventional politics, and high cultural capital" how different kinds of political consumption in a Canadian context are associated with various conventional political behaviours. Their article provides novel vistas on the relationship between political consumption and conventional forms of politics. Those consumers making political choices are likely to demonstrate conventional political behaviours, without indications for a crowding out or substitution effect. However, their results highlight a particular exclusivity of political consumption as consumers' search for high social status. The following article of Zhang (2015) entitled “'Voting with Dollars': A Cross-polity and Multilevel Analysis of Political Consumerism" compares political consumption in 21 different countries. Based on the assumption that political consumerism consists of purchases on markets expressing political and societal concerns, he asks how these activities are influenced by individual and societal factors. The results indicate that individual-level political media uses, political orientation and demographics account for boycott behaviours. On societal level, political consumerism can be found in affluent societies with lower levels of political rights but higher levels of civil liberties. 
Alongside with the articles on challenging and supporting the notion of political consumption and political consumerism, the next two articles highlight empirical cases in which consumers aim for social change with their particular lifestyles. Coelho (2015) describes in her article "Fair Trade Consumers in Portugal: Values and Lifestyles" how consumption practices and lifestyles can be seen as strategies of collective action with the objective to promote social change. Her article focuses on social characteristics of particular groups of political consumers and related values and lifestyles. Through sociological portraits, she detects three political consumer profiles: rational-instrumental consumers, rational-evaluative consumers and evaluative consumers. Another empirical example is presented by the article of Hakala et al. (2015) entitled "Young Finnish and German Consumers' Furniture Acquisition - Wooden, Inherited or Just Low Price?”, in which they depict home decorating as constructing identity and reflecting individual taste. Home decorating thereby is associated with particular values and lifestyles: their results emphasize meaningful consumption practices as influenced by aesthetics, functionality and the environment.

With these examples above, we can theoretically as well as empirically challenge the notion of consumption being political. To a particular extent, contexts matter, thus we proceed to the next streams of articles in this special issue on organisations and mobilising spaces. These papers represent distinct perspectives how consumption and lifestyles are organised in and around spaces, and furthermore, actors are mobilised in the localised settings.

\section{Organisations and mobilising spaces}

With the primary aim for social change, it seems that traditional movements are to a certain extent organised. There are social movement organisations giving way to organise participants. Even though lifestyle movements might be less involved in organised collective action, there are to some extent ways of organising consumers, as for instance in local initiatives. The first three papers in this stream show how particular initiatives are opposing market logics and alternative lifestyles in urban gardening, time banking and eco-villages are organised. On the other hand, the next three papers highlight how mobilising is to a growing extent taking place in online environments such as Twitter and Facebook. 
Dobernig and Stagl (2015) provide in their article "Growing a lifestyle movement? Exploring identity-work and lifestyle politics in urban food cultivation" a glimpse on how local lifestyles in New York City blur the boundaries between consumption and production. According to their respondents, urban food cultivation is a counter-hegemonic strategy of the political consumer with various motives and concerns. Identities of food producer-consumers relate to shared ethoses of re-engagement with nature, meaningful work, and authenticity and might on individual level induce collective social change. The next article by Laamanen et al. (2015) entitled "Mobilising collaborative consumption lifestyles: A comparative frame analysis of time banking" compares local mobilisation by time banks in London, Helsinki and The Hague. Their comparison relates collaborative consumption and lifestyle movements to cultural processes of meaning making and practices of framing, through which time banks mobilise constituents and entice collective action. Their findings highlight framing as a practice that challenges traditional monetised ideology of exchange in orthodox economic theory and the hegemonic understandings of consumption.

Another example of communities thriving for change is provided in the article of Brombin (2015): “Faces of sustainability, in Italian Ecovillages. Food as 'contact zone"”. The article describes the organisation of communities in Italian ecovillages around selfsufficient and alternative food production. These communities criticize the economic logic of economic market exchange and promote reciprocity and solidarity. Associated lifestyles endorse a holistic view of living, including pleasure, conviviality and restoring relationships of trust and sharing. Along with urban food cultivation, time banking and ecovillages, it is possible to describe mobilisation beyond organisations, moving toward a virtual setting for mobilising, which is discussed in the following three articles.

The article of Hwang and Kim (2015) entitled "Social Media as a Tool for Social Movements: The Effect of Social Media Use and Social Capital on Intention to Participate in Social Movements" assumes social media as an effective tool for mobilisation. The article verifies the relationship of social media use social movement participation in a Korean context and contributes perspectives on social capital and mobilisation. Weij et al. (2015) provide with their article "The appeal of contemporary protesting artists: Western solidarity with Pussy Riot and the Twittering of cosmopolitan selves" an explanation for the widespread attention of Western audiences to Russian political protesting artists Pussy Riot. They use cosmopolitanism to describe how Twitter users perform cosmopolitan selves by sharing their ideas and experiences. However, in the end, even though users do talk about Pussy Riot, 
these users do not necessarily become mobilised and being ready to participate in political advocacy.

The last article in this stream is written by de la Peña and Quintanilla (2015): "Share, like and achieve: The power of Facebook to reach health related goals". The article is concerned with the fact that individual consumers want to change, however, actually do not change their lifestyle. In a health setting, they consider virtual self-help groups as movements to assist meeting health related goals. Thus, social networking sites can be considered virtual communities mobilising and activating individuals. This stream shows how particular organisations and activities might (virtually) mobilise consumers to contribute to (social) change on a more collective level. In the next stream we are going to have a look at more particular mechanisms of mobilisation.

\section{Mechanisms of mobilisation}

Mobilisation can come across in different guises. Beyond online technologies, we can see that from historical perspectives, discursive practices, attitudes, coping strategies, selforganising, empowerment and motivations lead to mobilisation of individuals. All these diverse strategies or mechanisms can be sub-summed as ways for mobilising consumer in their lifestyles to aim for social change. The articles of this third and last stream of the special issue are described in the following paragraphs.

Wahn (2015) discusses in his article "The transformation of consumer movements through democratization and the development of civil society in Taiwan" the interplay between the development of civil society, consumer organisations and other social movements. He depicts the Taiwanese consumer movement as a showcase for developments of consumer protection and market deregulation. Thereby it is possible to underline a positive collaboration between different groups in order to become more effective and critical towards market conditions and their social consequences. Helm et al. (2015) advance in their article "Consumer Cynicism: Developing a Scale to Measure Underlying Attitudes Influencing Marketplace Shaping and Withdrawal Behaviors" the construct of consumer cynicism as a way of mobilising consumers. Cynical attitudes and resentment are pervasive in society and can be found on a wide range: from unobtrusive everyday consumer choices towards organised activism in traditional movements. As in current capitalist societies markets are 
ubiquitous, consumers aim to show their mistrust, becoming involved in shaping markets by criticism or develop withdrawal behaviour through their lifestyle.

Moruzzi and Sirieix (2015) provide in their article "Paradoxes of sustainable food and consumer coping strategies: A comparative study in France and Italy" a comparison of consumer perceptions in France and Italy. They look at sustainable food consumption paradoxes and related coping strategies: avoidance and problem solving. They conclude that mobilisation of consumers in sustainable food movements depends on context as well as the cultural conditions. The next article of Forno (2015) is set in the Italian context as well: "Bringing together scattered and localized actors: Political consumerism as a tool for selforganising anti-mafia communities”. She elaborates on efforts of a local Sicilian social movement organisation that mobilises community participants in Palermo in symbolic, material and structural dimensions. Anti-Mafia movement activists used the market as a political arena against organised crime. The study shows how personalisation of politics ultimately lead to sustained and public political engagement, yet only within certain areas or certain demographic groups.

McShane and Sabadoz (2015) re-evaluate the complex concept of consumer empowerment in their article "Rethinking the Concept of Consumer Empowerment: Recognizing Consumers as Citizens”. They approach consumer empowerment through a critical historical analysis in order to critically examine and deconstruct the concept in relation to consumer choice. The authors develop an alternate definition of the concept embracing the citizenship role enacted by individuals in their daily lives. The special issue comes to a close with Gotlieb's (2015) article "Civic, Cooperative, or Contrived? A Functional Approach to Political Consumerism Motivations", where she engages with the question whether and how political consumerism privatises politics and hinders public engagement by examining which motivations drive political consumerism. The paper introduces a framework for theorising ethical purchasing with scale measuring valueexpressive, social-identification, and social-approval motivations for political consumerism. The findings highlight the importance of (symbolic) motivations, values and personality traits for mobilising individual young consumers for more societal collective change. The papers of this stream show a multitude of approaches and ways of mobilising consumers in their everyday. In what follows we would like to highlight possible avenues for further investigation. 


\section{Conclusion - a research agenda}

In the introduction of this editorial we emphasise the paradox of the collective character of individualised activity with the intention for social change through consumption and lifestyles. We brought forward the associated question: Why, how and where do people come to share a common space, meaning, identity, practice and goals in dispersed lifestyles? Whereas we are able to find some answers to the above question in the articles published in this special issue, we believe that there is still ample room for further research in the conjuncture of social movement research and consumer studies. In the remainder of this editorial we would like to highlight how the question has been approached in the papers of the special issue and where potential for future research is envisioned.

This special issue was conceived to unfold avenues for a theoretical reorientation on (1) the genealogy of the understanding or conceptualisations of what or who is a consumer in relation to social movements, and to (2) move the discussion on lifestyles beyond hegemonic understandings of the individual consumer as market participant. Indeed, we needn't beseech an image of a consumer as homo economics or muster consumption as located in the sphere of purely economic activity: a good number of contributions in this special issue challenge consumer rationality (see Coelho, 2015; McShane and Sabadoz, 2015) and perceive political consumption coinciding with other forms of political activity (see Baumann et al., 2015; Dubuisson-Quellier, 2015; Forno, 2015; Gotlieb, 2015; Hwang \& Kim, 2015; McShane \& Sabadoz, 2015; Zhang, 2015). These aforementioned contributions enable a wider perspective into the nature of consumption as activism, resistance and civil participation, whereas others challenge the traditional understanding of consumption as an individualised act.

The examples of localised alternative communities (Brombin, 2015; Dobernig \& Stagl, 2015; Laamanen et al., 2015) envisage spaces at the intersection of the private and the public as well as production and consumption - prosumption and co-production (e.g. Bossy, 2014). With these contributions we can see how consumers enact alternatives, practice change and "do politics" in the everyday in a way that doesn't necessarily relate to the hegemonic understanding of the consumer as market participant or citizen as political actor. Similarly, articles of this special issue underline how we can challenge the individualised understandings of political consumerism (Balsinger, 2010; Holzer, 2006) by visualising collective action frames (Dubuisson-Quellier, 2015; Laamanen et al., 2015), and other tactics of mobilisation, such as drawing from other social movement experience or consumer 
cynicism (Forno, 2015; Helm et al., 2015; Wahn, 2015). Others (de la Peña and Quintanilla, 2015; Hakala et al., 2015; Weij et al., 2015) elaborate on the dynamic ways in which lifestyle politics and the practices of daily life and the self are enacted through consumption choices.

Where the contributions to this special issue illustrate political consumption and collective lifestyles, and how these are organised and mobilised in various spaces, we call for further efforts in deconstructing the separation between the private and public as well as the individual and collective. Indeed, in collective action enacted through consumption, the private becomes public in the shared identities and practices of a lifestyle (see Dobernig \& Stagl, 2015). Nevertheless, the instances where these distinctions become unravelled remain opaque. The individual and collective implications of lifestyle movements need further attention (Haenfler et al., 2012). In a similar vein, several studies in this special issue (Baumann et al., 2015; Coelho, 2015; Forno, 2015; Hwang \& Kim, 2015) referred to elitism, whereby political consumption becomes a cultural practice sustaining markers and boundaries, and access to resources and cultural capital to those who are able to "vote with their wallets or shopping baskets" or are capable to access information and networks of participation. Thus, further research is needed on the complexity and nuances of political lifestyle practices (Baumann et al., 2015; Portwood-Stacer, 2012; Yates, 2015), particularly amongst those less literate or capable on the market, or those living in less advantaged communities and societies. The intersection of politics of consumption and everyday practices still compels further exploration.

Some research in this issue (McShane \& Sabadoz, 2015; Moruzzi \& Sirieix, 2015;) also suggests the value of "market tripartism" or collective meaning creation between several market participants. Issues such as consumer awareness and empowerment to act sustainably can be analysed as nested within fields of strategic practice where various actors negotiate and contest understandings, responsibilities, motivations and roles, amongst others (see Laamanen \& Skålén, 2014). Such an analysis would further particularise power around consumption settings or how consumers resist domination on the market (cf. Bossy, 2014; Portwood-Stacer, 2012). Following Kozinets and Handelman (2004), further research is also needed on the ideologies of mobilisation. This can include the lifestyles and practices the individuals need to adopt in order to become legitimate participants, or how prefiguration influences the mobilisation of a lifestyle (cf. Haenfler et al., 2012; Yates, 2015). Extending on ideological practices, Dubuisson-Quellier (2015) points out to an interesting problem where social change projects of consumer movements become the new vehicles of capitalism, 
that is, lifestyles become appropriated by the market rather than functioning as the mechanisms that change it.

This special issue concentrates on scrutinising the politics of the everyday in consumption, lifestyles and social movements. Following the call by Haenfler et al. (2012; see also Forno, 2015 and Wahn, 2015), we further need to conceptualise the links between the contents and contexts of consumption, such as the links between lifestyles and lifestyle movements, representative politics, and other social movements. In the future, the impact of political consumption and consumer movements in various (cross-)national contexts and in relation to national politics should be examined (Baumann et al., 2015; Yates, 2015; Zhang, 2015). In general, research on particular histories, tactics, efficiencies, and paths that lifestyle movements pursue are urgently needed.

\section{Acknowledgements}

We wish thank all the authors who submitted their work, and want to acknowledge the competent work of the reviewers without whom this special issue would not be possible. Our gratitude goes to the Editor of the journal, Katherine Hughes, for her invaluable support as well as the production team at Wiley for their continued efforts throughout the process. Few submissions unfortunately didn't make it in time for this special issue and will be published in the regular issue of the journal.

\section{References}

Balsiger, P. (2010) Making Political Consumers: The Tactical Action Repertoire of a Campaign for Clean Clothes. Social Movement Studies, 9 (3), 311-329. DOI:10.1080/14742837.2010.493672

Bauman, Z. (2005) Work, Consumerism and the New Poor, 2nd edn. Open University Press, Maidenhead, UK.

Baumann, S., Engman, A. \& Johnston, J. (2015) Shopping for change?: Political consumption, conventional politics, and high cultural capital. International Journal of Consumer Studies, 39 (5), 413-421. DOI:10.1111/ijcs. 12223

Bossy, S. (2014) The utopias of political consumerism: The search of alternatives for mass consumption. Journal of Consumer Culture, 14 (2), 179-198. 
Brombin, A. (2015). Faces of sustainability, in Italian Ecovillages. Food as "contact zone". International Journal of Consumer Studies, 39 (5), 468-477. DOI:10.1111/ijcs.12225

Coelho, S. (2015) Fair trade consumers in Portugal: Values and lifestyles. International Journal of Consumer Studies, 39, 437-444. DOI: 10.1111/ijcs. 12232

de Certeau, M. (1984) The Practice of Everyday Life. University of California Press, Berkeley, CA, USA.

de la Peña, A. \& Quintanilla, C. (2015) Share, like and achieve: The power of facebook to reach health related goals. International Journal of Consumer Studies, 39 (5), XX. DOI:10.1111/ijcs.12224

Della Porta, D. \& Diani, M. (2006) Social Movements, 2nd edn. Wiley, Chichester, UK.

Dobernig, K. \& Stagl, S. (2015) Growing a lifestyle movement? Exploring identity-work and lifestyle politics in urban food cultivation. International Journal of Consumer Studies, 39 (5), 452-458. DOI:10.1111/ijcs. 12222

Dubuisson-Quellier, S. (2013) Ethical Consumption. Fernwood Publishing, Black Point, NS, Canada.

Dubuisson-Quellier, S. (2015) From targets to recruits: the status of consumers within the political consumption movement. International Journal of Consumer Studies, 39 (5), 404-412. DOI:10.1111/ijcs.12200

Farrell, C. (2010) Citizen and consumer involvement in UK public services. International Journal of Consumer Studies, 34 (5), 503-507. DOI:10.1111/j.1470$6431.2010 .00915 . \mathrm{x}$

Firat, A. F. \& Venkatesh, A. (1995) Liberatory Postmodernism and the Reenchantment of Consumption. Journal of Consumer Research, 23 (4), 326-350.

Forno, F. (2015) Bringing together scattered and localized actors: Political consumerism as a tool for self-organizing anti-mafia communities. International Journal of Consumer Studies, 39 (5), 535-543. DOI:10.1111/ijcs.12233

Forno, F. \& Graziano, P.R. (2014) Sustainable community movement organisations. Journal of Consumer Culture, 14 (2), 139-157. DOI:10.1177/1469540514526225

Futrell, R. \& Simi, P. (2004) Free Spaces, Collective Identity, and the Persistence of U.S. White Power Activism. Social Problems, 51 (1), 16-42. DOI:10.1525/sp.2004.51.1.16 
Gabriel, Y. \& Lang, T. (2006) The Unmanageable Consumer. 2nd edn. Sage, London, UK.

Giddens, A. (1991) Modernity and Self-identity: Self and Society in the Late Modern Age. Stanford University Press, Stanford, CA, USA.

Ginsborg, P. (2005) The politics of everyday life: making choices, changing lives. Yale University Press, New Haven, CT, USA.

Glickman, L.B. (2009) Buying power: A history of consumer activism in America. University of Chicago Press, Chicago, IL, USA.

Gotlieb, M.R. (2015) Civic, Cooperative, or Contrived? A Functional Approach to Political Consumerism Motivations. International Journal of Consumer Studies, 39 (5), 552563. DOI: $10.1111 /$ ijcs.12227

Haanpää, L. (2007) Consumers' green commitment: indication of a postmodern lifestyle? International Journal of Consumer Studies, 31 (5), 478-486. DOI:10.1111/j.1470-6431.2007.00598.x

Hakala, I., Autio, M. \& Toppinen A. (2015) Young Finnish and German consumers' furniture acquisition - wooden, inherited or just low price? International Journal of Consumer Studies, 39 (5), 445-451. DOI:10.1111/ijcs.12189

Halkier, B. \& Holm, L. (2008) Food consumption and political agency: on concerns and practices among Danish consumers. International Journal of Consumer Studies, 32 (6), 667-674. DOI:10.1111/j.1470-6431.2008.00695.x

Haenfler, R., Johnson, B. \& Jones, E. (2012) Lifestyle Movements: Exploring the Intersection of Lifestyle and Social Movements. Social Movement Studies, 11 (1), 120. DOI:10.1080/14742837.2012.640535

Helm, A.E., Moulard, J.G. \& Richins, M. (2015). Consumer cynicism: Developing a scale to measure underlying attitudes influencing marketplace shaping and withdrawal behaviors. International Journal of Consumer Studies, 39 (5), 515-524. DOI:10.1111/ijcs.12191

Holt, D. B. (1997) Poststructuralist Lifestyle Analysis: Conceptualizing the Social Patterning of Consumption in Postmodernity. Journal of Consumer Research, 23 (4), 326-350 
Holzer, B. (2006) Political consumerism between individual choice and collective action: social movements, role mobilization and signalling. International Journal of Consumer Studies, 30 (5), 405-415. DOI:10.1111/j.1470-6431.2006.00538.x

Hwang, H. \& Kim, K-O. (2015) Social Media as a Tool for Social Movements: The Effect of Social Media Use and Social Capital on Intention to Participate in Social Movements. International Journal of Consumer Studies, 39 (5), 478-488. DOI:10.1111/ijcs.12221

Johnston, H. \& Klandermans, B. (1995) The Cultural Analysis of Social Movements. In: Social Movements and Culture (Social Movements, Protest, and Contention, Volume 4) (ed. by H. Johnston \& B. Klandermans), pp. 3-24. University of Minneapolis Press, Minneapolis, MN, USA.

King, B. G. (2011) The Tactical Disruptiveness of Social Movements: Sources of Market and Mediated Disruption in Corporate Boycotts. Social Problems, 58 (4), 491-517. DOI: $10.1525 /$ sp.2011.58.4.491

Klintman, M. (2006) Ambiguous framings of political consumerism: means or end, product or process orientation? International Journal of Consumer Studies, 30 (5), 427-438. DOI:10.1111/j.1470-6431.2006.00540.x

Kozinets, R. \& Handelman, J.M. (2004) Adversaries of Consumption: Consumer Movements, Activism, and Ideology. Journal of Consumer Research, 31 (3), 691704. DOI:10.1086/425104

Laamanen, M. \& Skålén, P. (2014) Collective-conflictual value co-creation: A strategic action field approach. Marketing Theory. Accepted Article, DOI:10.1177/1470593114564905

Laamanen, M., Wahlen, S. \& Campana, M. (2015) Mobilising collaborative consumption lifestyles: A comparative frame analysis of time banking. International Journal of Consumer Studies, 39 (5), 459-467. DOI:10.1111/ijcs.12190

Lichterman, P. (1996) The search for political community. Cambridge University Press, Cambridge, UK.

Lury, C. (2011) Consumer Culture. 2nd edn. Polity, Cambridge, UK.

Maeckelbergh, M. (2009) The Will of the Many: How the Alterglobalization Movement is Changing the Face of Democracy. Pluto Press, London, UK. 
McShane, L. \& Sabadoz, C. (2015) Rethinking the concept of consumer empowerment: recognizing consumers as citizens. International Journal of Consumer Studies, 39 (5), 544-551. DOI:10.1111/ijcs. 12186

Micheletti, M. (2003) Political Virtue and Shopping. Individuals, Consumerism, and Collective Action. Palgrave Macmillan, New York, NY, USA.

Moisander, J. (2007) Motivational complexity of green consumerism. International Journal of Consumer Studies, 31 (4), 404-409. DOI:10.1111/j.1470-6431.2007.00586.x

Moraes, C., Szmigin, I. \& Carrigan, M. (2010) Living production-engaged alternatives: An examination of new consumption communities. Consumption, Markets \& Culture, $\mathbf{1 3}$ (3), 273-298. DOI:10.1080/10253861003787015

Moruzzi, R. \& Sirieix, L. (2015) Paradoxes of sustainable food and consumer coping strategies: A comparative study in France and Italy. International Journal of Consumer Studies, 39 (5), 525-534. DOI:10.1111/ijcs. 12228

Portwood-Stacer, L. (2012) Anti-consumption as tactical resistance: Anarchists, subculture, and activist strategy. Journal of Consumer Culture, 12 (1), 87-105. DOI:10.1177/1469540512442029

Reedy, P. (2014). Impossible organisations: Anarchism and organisational praxis. ephemera: theory \& politics in organization, 14 (4), 639-658.

Snow, D. A. (2004) Social movements as challenges to authority: Resistance to an emerging conceptual hegemony. In: Authority in Contention (Research in Social Movements, Conflict, and Change, Volume 25) (ed. by D.J. Meyers \& D.M. Cress), pp. 3-25. JAI Press, Greenwich, CT, USA.

Snow, D. A. \& Soule, S. A. (2010) Primer on Social Movements. W. W. Norton \& Co, New York, NY, USA.

Soule, S. A. (2012) Social Movements and Markets, Industries, and Firms. Organization Studies, 33 (12), 1715-1733. DOI: 10.1177/0170840612464610

Stolle, D., Hooghe, M. \& Micheletti, M. (2005) Politics in the Supermarket: Political Consumerism as a Form of Political Participation. International Political Science Review, 26 (3), 245-269. DOI:10.1177/0192512105053784 
Trentmann, F. (2006) Knowing consumers - Histories, identities, practices: An Introduction. In: Frank Trentmann (ed.) The making of the consumer. Knowledge, power and identity in the modern world (pp. 1-27). Oxford: Berg Publishers.

Varman, R. \& Belk, R. W. (2009) Nationalism and Ideology in an Anticonsumption Movement. Journal of Consumer Research, 36 (4), 686-700. DOI: 10.1086/600486

Wahlen, S. (2009) The consumer stuck between a rock of victimhood and a hard place called responsibility. International Journal of Consumer Studies, 33 (4), 361-368. DOI:10.1111/j.1470-6431.2009.00788.x

Wahlen, S. (2011) The routinely forgotten routine character of domestic practices. International Journal of Consumer Studies, 35 (5), 507-513. DOI:10.1111/j.14706431.2011.01022.x

Wahn, I-L. (2015) The transformation of consumer movements through democratization and the development of civil society in Taiwan. International Journal of Consumer Studies, 39 (5), 506-514. DOI:10.1111/ijcs.12226

Warde, A. (2005) Consumption and Theories of Practice. Journal of Consumer Culture 5 (2), 131-153. DOI:10.1177/1469540505053090.

Weij, F., Berkers, P. \& Engelbert, J. (2015) The appeal of contemporary protesting artists: Western solidarity with Pussy Riot and the Twittering of cosmopolitan selves. International Journal of Consumer Studies, 39 (5), 489-494. DOI:10.1111/ijcs. 12215

Yates, L. (2011) Critical consumption - Boycotting and buycotting in Europe. European Societies, 13 (2), 191-217. DOI:10.1080/14616696.2010.514352

Yates, L. (2015) Everyday politics, social practices and movement networks: daily life in Barcelona's social centres. The British Journal of Sociology, 66 (2), 236-258. DOI:10.1111/1468-4446.12101

Zhang, X. (2015) 'Voting with dollars': a cross-polity and multilevel analysis of political consumerism. International Journal of Consumer Studies, 39 (5), 422-436. DOI:10.1111/ijcs.12181 